\title{
A FURAZOLIDONE-BASED QUADRUPLE THERAPY FOR HELICOBACTER PYLORI RETREATMENT IN PATIENTS WITH PEPTIC ULCER DISEASE
}

\author{
Jaime Natan Eisig, Fernando Marcuz Silva, Tomás Navarro Rodriguez, Cláudio \\ Lyoti Hashimoto, and Ricardo Correa Barbuti
} Eisig JN, Silva FM, Rodriguez TN, Hashimoto CL, Barbuti RC. A furazolidone-based quadruple therapy for for helicobacter
pylori retreatment, in patients with with peptic ulcer disease. Clinics. 60(6):485-8.

PURPOSE: Many of the currently used eradication regimens against Helicobacter pylori fail to cure the infection either due to antimicrobial resistance or to poor patient compliance. The infection leads to increased risk of developing potentially severe complications, such as gastric cancer. This study was aimed at assessing the efficacy and safety of a quadruple therapy with furazolidone for $H$. pylori retreatment.

METHODS: Patients who had failed one or more eradication regimens against $H$. pylori infection underwent upper gastrointestinal endoscopy. Biopsy specimens were taken from the gastric antrum and corpus for histology and for a urease test and. Patients received omeprazole $20 \mathrm{mg}$, bismuth citrate $240 \mathrm{mg}$, tetracycline $500 \mathrm{mg}$, and furazolidone $200 \mathrm{mg}$, all twice daily for 7 days. Therapeutic success was evaluated by endoscopy and biopsies 8 weeks after the end of treatment.

RESULTS: Sixty two patients were enrolled, and 58 completed the study. Under this protocol, H. pylori eradication was achieved in 39/58 patients (67\%). Mild adverse events were reported.

CONCLUSION: The short quadruple therapy course with furazolidone is well tolerated, inexpensive, and effective in retreatment for $\mathrm{H}$. pylori infection. It is a good option for developing countries.

KEYWORDS: Peptic ulcer treatment. Helicobacter pylori eradication. Resistant Helicobater pylori. Quadruple therapy. Furazolidone.

The importance of $H$. pylori as an etiological factor in gastrointestinal ulcer is well established, and its eradication is the main objective in the treatment of peptic ulcer disease. ${ }^{1-3}$

First-line eradication therapies for H. pylori associate a proton-pump inhibitor with 2 types of antibiotics; this results in eradication rates of $80 \%$ to $90 \%$. Consequently, $10 \%$ to $20 \%$ of patients will constitute therapeutic failure,, 5 the main reasons being low patient compliance with treatment $^{6}$ and bacterial resistance to the antimicrobial agents, ${ }^{7}$ especially to clarithromycin and metronidazole. ${ }^{8}$

The best retreatment regime has yet to be established. Some international consensus statements recommend the use of a quadruple therapy regime with a proton-pump inhibitor, bismuth subcitrate, metronidazole, and tetracycline

Department of Gastroenterology, Hospital das Clínicas, São Paulo University Medical School - São Paulo/SP, Brazil.

Email: jeisig@attglobal.net

Received for publication on July 04, 2005.

Accepted for publication on September 30, 2005. for 1 week, resulting in eradication rates of $57 \%$ to $95 \%$, with an average of $77 \% .^{4}$

A retreatment option that is more practical in Brazil involves the use of furazolidone. In a country such as ours, which has large populations with low socioeconomic levels and high bacterial resistance to metronidazole,${ }^{8}$ a simple, inexpensive regime that is reasonably well tolerated by patients is one that substitutes metronidazole with furazolidone.

This study aimed at establishing the efficacy and safety of a 7-day therapeutic regimen used in the eradication of H. pylori using omeprazole, bismuth subcitrate, tetracycline, and furazolidone in a group of patients with peptic ulcer disease who had been previously treated with other therapeutic regimens without success.

\section{METHODS}

Patients were selected from the Outpatient Gastroenterology Clinic of Hospital das Clinicas, Faculty of Medicine, 
University of São Paulo (HCFMUSP). The study was approved by the institutional Ethics Review Board for clinical research, and all patients signed an informed written consent form. Sixty-two patients with peptic ulcer who had previously been treated unsuccessfully with one or more eradication regimens for Helicobacter pylori (Table 1) were included in the study. Bacterial persistence after treatment was confirmed by positivity of the rapid urease test and histological examination through a modified Giemsa staining method. Gastric mucosa samples were obtained from the antrum and corpus through upper digestive endoscopy.

Patients who were younger than 18 years of age were excluded, as were those who presented severe comorbidity, pregnant patients, infants, patients who had previously undergone gastrectomy, patients with a known history of allergy to the therapeutic regime drugs, and patients who had used nonsteroidal antiinflammatory drugs (NSAIDs), antibiotic therapy, or bismuth salts up to 4 weeks before study inclusion.

In an open, cohort study, the patients were invited to use a therapeutic regime for 7 days that consisted of 20 mg omeprazole, $240 \mathrm{mg}$ colloidal bismuth subcitrate, 500 $\mathrm{mg}$ tetracycline, and $200 \mathrm{mg}$ furazolidone, taken twice a day. Patients were warned not to ingest alcoholic beverages and to avoid foods related to potential side effects determined for drugs similar to monoamine oxidase inhibitors. They were also encouraged to take the full medication regularly and were informed about the importance of an adequate use of the medication for a successful treatment. No other medication was allowed until the end of the treatment, when patients were evaluated regarding compliance by counting the remaining tablets. Adverse effects were recorded in a questionnaire, and each adverse effect was specifically investigated.

Treatment efficacy was determined by bacterial negativity at the rapid urease test and histological examination of gastric antrum and corpus mucosa samples taken during digestive endoscopy performed 8 weeks after the end of treatment.

\section{Statistical Analysis}

Sample size calculation was determined for a descriptive study of a dichotomous variable, considering the prevalence of peptic ulcer with resistant Helicobacter pylori in $2 \%$ of the general population and an expected eradication efficacy of $70 \%$. The eradication rates were calculated by intention to treat and per protocol analysis.

All patients enrolled in the study were analyzed as intention to treat (ITT). All the patients enrolled who took more than $80 \%$ of the medication and those who returned and agreed to undergo the control endoscopy were considered for the per protocol (PP) analysis. A confidence in- terval of $95 \%$ was calculated for the eradication rate percentiles. The chi-square method with Pearson coefficient was used for the comparison among the variables, eradication rate for previous treatment, gender, and age, with a significance value of $P<.05$.

Statistical calculations were performed with the SPSS statistics software, version 10.0 (SPSS Inc., USA).

\section{RESULTS}

Of the 62 patients enrolled in the study, a few had already undergone 3 or more previous treatments (Table 1 ). There was no predominance regarding gender, and the average and median age of patients was 45 years. The prevalence of duodenal ulcer was high, and the prevalence of smokers was similar to that in the Brazilian population ${ }^{9}$ (see Table 2). Four patients were excluded from the analysis by protocol, 2 for failing to undergo the control endoscopy, 1 for taking the medication inadequately, and 1 who interrupted the treatment early due to the presence of adverse effects (nausea and headaches).

The eradication rates were $67 \%$ (39/58) for the PP group and $63 \%$ (39/62) for the ITT group (Table 3). There was no difference in the eradication rates in relation to the number of previous treatments the patient had undergone (Table 4). Age and gender did not correlate with eradication rates either. Adverse effects were reported by $10 \%$ of the patients, and these were usually considered to be slight. Only 1 patient had to withdraw from treatment due to the presence of nausea and headaches.

Table1 - Unsuccessful previous treatments

\begin{tabular}{ll}
\hline Therapies & Patients \\
\hline 1 & 37 \\
2 & 20 \\
3 or more & 5 \\
Total & 62 \\
\hline
\end{tabular}

Table 2 - Clinical data

\begin{tabular}{lll}
\hline Patients & & 62 \\
Age (years) & mean & 45 \\
& Median & 45 \\
& Interval & $18-74$ \\
Women & & $50 \%$ \\
Duodenal ulcer & $71 \%$ \\
Tobacco users & $22 \%$ \\
\hline
\end{tabular}

Table 3 - Eradication rates

\begin{tabular}{lll}
\hline & $\%$ & $95 \%$ Confidence Interval \\
\hline Per protocol & $67 \%(39 / 58)$ & $80 \%-55 \%$ \\
Intention to treat & $63 \%(39 / 62)$ & $51 \%-75 \%$ \\
\hline
\end{tabular}


Table 4 - Eradication rates and previous treatments

\begin{tabular}{ll}
\hline Treatments & Rates \\
\hline 1 & $65 \%(23 / 58)$ \\
2 & $74 \%(14 / 58)$ \\
3 or more & $60 \%(3 / 5)$ \\
\hline
\end{tabular}

\section{DISCUSSION}

In recent years, an increase in the number of patients who present therapeutic failure with $H$. pylori eradication regimens has been observed. Antimicrobial resistance has been described as the main reason for this failure. Thus, several alternative therapeutic regimens have been tested with the objective of attaining an effective retreatment of such patients.

In our country, it is costly and unfeasible to verify antimicrobial sensitivity in all patients who need retreatment, even for large centers, and few of them perform the bacterial sensitivity test. Hence, retreatment regimens are not based on the antibiogram of the resistant Helicobacter, but rather on the knowledge of the previously used antibiotic therapy.

In this study, many patients were referred from other medical centers and had previously been treated with different drug regimens, with clarithromycin and metronidazole being the most frequently used antibiotics.

It is known that clarithromycin and metronidazole resistance is common in all parts of the world and that it has been increasing. ${ }^{10-15}$ In developing countries, where the use of metronidazole is very common in the treatment of parasitic infestations, $40 \%$ to $70 \%$ of the strains are resistant to this drug. ${ }^{12,16,17}$

Furazolidone is a synthetic nitrofuran derivative with bactericidal or bacteriostatic activity when used against
Gram-positive and Gram-negative bacteria, and it is well absorbed in the intestine with no tissue accumulation. ${ }^{18-20}$ It has been used in China for more than 20 years in the treatment of peptic ulcer as the single therapeutic agent, with healing rates comparable to those obtained with cimetidine and displaying lower recidivation rates. ${ }^{21,22}$ It is currently known that the good results are mostly due to its anti-H. pylori activity. ${ }^{23,24}$

Furazolidone-resistant strains ${ }^{25,26}$ have not been described to date, which makes its use an alternative in the retreatment of peptic ulcer disease caused by $H$. pylori.

One of the great impediments regarding the use of furazolidone is its association with significant adverse effects, reported mainly in studies carried out in Europe, where it is no longer considered a drug of choice for retreatment regimens. ${ }^{27,28}$ Our study, however, produced different results from those found in the literature, since only 1 patient had to interrupt the treatment due to the presence of side effects.

The eradication rates (67\% PP and 63\% ITT) were a little lower than those reported in other studies based on this therapeutic regimen. ${ }^{29} \mathrm{It}$ is possible that the use of only $1 \mathrm{~g} /$ day of tetracycline and $400 \mathrm{mg} /$ day of furazolidone may explain the results obtained. With the aim of achieving a higher compliance rate by patients with the quadruple therapeutic regime, it was administered for only 7 days, although several consensus statements suggest a 14-day duration. ${ }^{30,31}$ It is possible that a more prolonged treatment might result in better eradication rates.

In conclusion, our study showed that the association of furazolidone with a proton-pump inhibitor plus tetracycline and colloidal bismuth subcitrate could be a valuable alternative for patients who need retreatment for $H$. pylori eradication. It is an effective, affordable treatment that allows good compliance and produces low adverse effect rates.

\section{RESUMO}

Eisig JN, Silva FM, Rodriguez TN, Hashimoto CL, Barbuti RC. Esquema quádruplo com furazolidona para retratamento do Helicobacter Pylori, em pacientes ulcerosos. Clinics. 60(6):485-8.

OBJETIVO: Muitos dos esquemas atualmente usados na erradicação do Helicobacter pylori não conseguem curar a infecção, pela resistência bacteriana ou pela baixa adesão do paciente. Esta condição manterá os riscos de desenvolvimento das potenciais complicações graves da infecção. Este estudo procurou determinar a eficácia e segurança de um esquema quádruplo que associou a furazolidona para o retratamento da infecção pelo H. pylori.
MÉTODOS: Pacientes que não alcançaram erradicação em um ou mais tratamentos foram submetidos à endoscopia digestiva alta e dois fragmentos do antro e do corpo foram retirados para exame histológico e de urease. Receberam então $20 \mathrm{mg}$ de omeprazol, $240 \mathrm{mg}$ de sub-citrato de bismuto, $500 \mathrm{mg}$ de tetraciclina e $200 \mathrm{mg}$ de furazolidona duas vezes ao dia por 7 dias. O sucesso terapêutico foi determinado pela negativação de nova biópsia endoscópica, após 8 semanas do tratamento.

RESULTADOS: Sessenta e dois pacientes foram incluídos, cinqüenta e oito completaram o estudo. Por protocolo, 67\% (39/58) dos pacientes conseguiram a erradicação da bactéria. Efeitos adversos leves foram relatados. 
CONCLUSÃO: O tratamento de curto prazo, em esquema quádruplo com a furazolidona, é bem tolerado, barato e eficaz no re-tratamento do H. pylori. Uma boa opção de re-tratamento para países em desenvolvimento.
PALAVRAS-CHAVE: Úlcera péptica. Tratamento. Helicobacter pylori. Erradicação. Helicobacter pylori resistente. Terapia quádrupla. Furazolidona.

\section{REFERENCES}

1. NIH Consensus Development Panel. Helicobacter pylori in peptic ulcer disease. J Am Med Assoc. 1994;272:65-9.

2. The European Helicobacter Study Group. Current European concepts in management of Helicobacter pylori infection. The Maastricht Consensus Report Gut. 1997;41:8-13.

3. Lam SK, Talley NJ. Report of the 1997 Asia Pacific consensus conference on the management of Helicobacter pylori infection. $\mathrm{J}$ Gastroenterol Hepatol. 1998;134:1-12.

4. Gisbert JP, Pajares JM. Review article: Helicobacter pylori "rescue" regimen when proton pump inhibitor-based triple therapies fail. Aliment Pharmacol Ther. 2002;16:1047-57.

5. Parente F, Cucino C, Bianchi-Porro G. Treatment options for patients with Helicobacter pylori infection resistant to one or more eradication attempts. Dig Liver Dis. 2003;35:523-8.

6. Graham DY, Lew GM, Malaty HM, Evans DG, Jr Klein PD, Alpert LC, et al. Factors influencing the eradication of Helicobacter pylori with triple therapy. Gastroenterology. 1992;102:493-6.

7. Houben MH, Van Der Beek D, Hensen EF, Craen AJ, Rauws EA, Tytgat GN. A systematic review of Helicobacter pylori eradication therapy. The impact of antimicrobial resistance on eradication rates. Aliment Pharmacol Ther. 1999;13:1047-55.

8. Mendonça S, Ecclissato C, Sartori MS, Godoy AP, Guerzoni RA, Degger $\mathrm{M}$, et al. Prevalence of Helicobacter pylori resistance to metronidazole, clarithromycin, amoxicillin, tetracycline and furazolidone in Brazil. Helicobacter. 2000;5:79-83.

9. Brasil. Ministério da Saúde. Instituto Nacional do Câncer. Tabagismo in: Inquérito domiciliar sobre comportamentos de riscos e morbidade referida de doenças e agravos não transmissíveis: Brasil, 15 capitais e Distrito Federal, 2002-2003. Rio de Janeiro: INCA, 2004, p 51-67. Available from URL: www.inca.gov.br/inquerito

10. Wreiber K, Olsson-Liljequist B, Engstrand L. Development of resistant Helicobacter pylori in Sweden: tendency toward increasing resistance to clarithromycin. Lakartidningen. 1999;96:582-4.

11. Osato MS, Reddy R, Reddy SG, Penland RL, Malaty HM, Grahan DY. Pattern of primary resistance of Helicobacter pylori to metronidazole or clarithromycin in the United States. Arch Intern Med.2001;161:1217-20.

12. van der Hulst RW, Keller JJ, Raws EAJ, Tytgat GN. Treatment of Helicobacter pylori infection. A review of the world literature. Helicobacter. 1996;1:6-19.

13. Thijs JC, Zwet AA, Moolenaar W, Oom JA, De Korte-H, Runhaar EA. Short report: clarithromycin, an alternative to metronidazole in the triple therapy of Helicobacter pylori infection. Aliment Pharmacol Ther. 1994;8:131-4.

14. Soll AH. Consensus conference. Medical treatment of peptic ulcer disease. Practice guidelines. Practice parameters committee of American College of Gastroenterology. J Am Med Assoc. 1996;275:622-9.

15. Al-Assi AT, Ramirez FC, Lew GM, Genta RM, Graham DY. Clarithromycin, tetracycline, and bismuth: a new non-metronidazole therapy for Helicobacter pylori infection. Am J Gastroenterol. 1994;89:1203-5.
16. Salman-Raoghani H, Pahlewanzadeh MR, Dashti MA, Massarrat S. Effect of two different doses of metronidazole and tetracycline in classic triple therapy on eradication of $H$. pylori and its metronidazole resistant strains. Gastroenterology. 1997;112:A 22.

17. Tytgat GNY. Aspects of Helicobacter pylori: Basic mechanism to clinical cure. Dordrecht: Kluwer Academic Publisher; 1996. p. 304.

18. Katzung BG. Basic Clinical Pharmacology. 2nd ed. California: Lange; 1984.

19. Goth A. Medical Pharmacology. 10th ed St. Louis: CV Mosby; 1981.

20. White AH. Absorption, distribution, metabolism, and excretion of furazolidone. A review of the literature. Scand J Gastroenterol Suppl. 1989;169:4-10.

21. Zheng ZT, Wang YB, Chu YX, Li YN, Li QF, Lin SR, et al. Doubleblind short-term trial of furazolidone in peptic ulcer. Chinese Medical Journal. 1985;98(8):616-7.

22. Zheng ZT, Wang YB. Treatment of peptic ulcer disease with furazolidone. J Gastroenterol Hepatol. 1992;7(5):533-7.

23. Howden A, Boswell P, Tovey F. In vitro sensitivity of Campylobacter pyloridis to furazolidone. Lancet. 1986;2:1035.

24. Graham DY, Klein PD, Opekum AR, Smith KE, Polasani RR, Evans Jr DJ, et al. In vivo susceptibility of Campylobacter pylori. Am J Gastroenterol. 1989;84:233-8.

25. Fakheri H, Merat S, Hosseini V, Malekzadeh R. Low-dose furazolidone in triple and quadruple regimens for Helicobacter pylori eradication. Aliment Pharmacol Ther. 2004;19:89-93.

26. Pourkhajeh A, Siavoshi F, Malekzadeh R, Massarrat S. In vitro sensitivity of Helicobacter pylori to antibiotics. Gastroenterology. 1999;116:A244.

27. Altamirano A, Bondani A. Adverse reactions to furazolidone and other drugs - a comparative review. Scand J Gastroenterol. 1989;24:70-80.

28. Fakheri H, Malekzadeh R, Merat S, Khatibian M, Fazel A, Alizadeh $\mathrm{BZ}$, et al. Clarithromycin versus furazolidone in quadruple therapy regimens for the treatment of Helicobacter pylori in a population with a high metronidazole resistance rate. Aliment Pharmacol Ther. 2001;15(3):411-6.

29. Treiber G, Ammon S, Malfertheiner P, Klotz U. Impact of furazolidonebased quadruple therapy for eradication of Helicobacter pylori after previous treatment failures. Helicobacter. 2002;7(4):225-31.

30. Megráud F, Lamouliatte H. Review article: the treatment of refractory Helicobacter pylori infection. Aliment Pharmacol Ther. 2003;17:133343.

31. Malfertheiner P, Mégraud FO`Morain C, Hungin AP, Jones R, Axon A, et al. Current concepts in the management of Helicobacter pylori infection - The Maastricht 2-2000 Consensus Report. Aliment Pharmacol Ther. 2002;16(2):167-80. 